\title{
Multidisciplinary analysis of Knemidocoptes jamaicensis parasitising the Common Chaffinch, Fringilla coelebs: proofs for a multispecies complex?
}

\author{
Jacek Dabert • Miroslawa Dabert • Adrian F. Gal • \\ Viorel Miclăuș • Andrei D. Mihalca • Attila D. Sándor
}

Received: 20 February 2013 / Accepted: 15 March 2013/Published online: 7 April 2013

(C) The Author(s) 2013. This article is published with open access at Springerlink.com

\begin{abstract}
The number of studies discussing the pathology and host specificity in Knemidocoptinae is very limited. In Knemidocoptes jamaicensis, the host specificity seems to be very broad, and there is a clear morphological variability in individuals originating from various bird species; hence, serious doubts appear about the species status of this mite. We report a multidisciplinary approach to the taxonomy, morphology, ecology, and pathology of $K$. jamaicensis. The source of the mites in our study was a second year aged female of the Common Chaffinch, Fringilla coelebs, which accidentally died in the mist net during a field study in Dumbrava, Cluj
\end{abstract}

All authors contributed equally to this paper.

J. Dabert

Department of Animal Morphology, Faculty of Biology,

Adam Mickiewicz University, Umultowska 89,

60-414 Poznan, Poland

\section{Dabert}

Molecular Biology Techniques Laboratory, Faculty of Biology, Adam Mickiewicz University, Umultowska 89,

60-414 Poznan, Poland

\section{A. F. Gal}

Department of Pathology, Faculty of Veterinary Medicine,

University of Agricultural Sciences and Veterinary

Medicine Cluj-Napoca, Calea Mănăștur 3-5,

Cluj-Napoca 400372, Romania

\section{Miclăuș}

Department of Histology, Faculty of Veterinary Medicine, University of Agricultural Sciences and Veterinary

Medicine Cluj-Napoca, Calea Mănăștur 3-5,

Cluj-Napoca 400372, Romania

A. D. Mihalca $(\triangle) \cdot$ A. D. Sándor

Department of Parasitology and Parasitic Diseases, Faculty of Veterinary Medicine, University of Agricultural Sciences and Veterinary Medicine Cluj-Napoca, Calea Mănăştur 3-5, Cluj-Napoca 400372, Romania

e-mail: amihalca@usamvcluj.ro
County, Romania in March 2011. Comparisons of the biometrical data regarding the body dimensions, length of certain setae, and distances between bases of dorsal setae with other published data showed a great variability of certain measurements between populations infecting various hosts and localities and sometimes even within single populations. Gross and histologic lesions consisted in severe bilateral orthokeratotic hyperkeratosis and epidermal spongiosis. Lesions also involved the skin of the joints. Skin inflammation was absent, and no lesions were noticed in the metatarsus bone. Following molecular analysis, the 518-base-long sequence differed from the published $18 \mathrm{~S}$ rDNA in nine positions. Additionally, our paper reports for the first time the DNA barcode sequences of $K$. jamaicensis and, together with the synoptic analysis of host spectrum, geographical distribution and morphological variability it brings important evidences to sustain the hypothesis of multispecies complex for $K$. jamaicensis.

\section{Introduction}

The members of the mite subfamily Knemidocoptinae (Acari; Astigmata; Epidermoptidae) are ectoparasites deeply penetrating the body surface of avian hosts and causing severe skin lesions in wide range of bird taxa (Mironov et al. 2005). The subfamily comprises 15 named species in six genera (Dabert et al. 2011). The microhabitats on the avian host body that may be inhabited by knemidocoptin mites include: (1) feather follicles and the stratum corneum of the face and cere (face mites), (2) the tissue under the scales on feet and legs (scaly leg mites), or (3) the feather bases on the body (depluming itch mites). Knemidocoptes jamaicensis (Turk 1950) belongs to the second ecological group, "scaly leg mites" (Langenscheidt 1958).

These mites may have a detrimental influence on the host condition; hence, they are among the most important pests of 
poultry and pet birds. However, there are few studies discussing the pathology and importance of knemidocoptins in wild birds. Moreover, in certain species of Knemidocoptinae, the host specificity is poorly studied, and routine species identification is usually based only on morphological features. Nevertheless, in $K$. jamaicensis, there is a clear morphological variability in individuals originating from various host species (see Fain and Elsen 1967). If we add this to the very broad host range and geographical distribution of $K$. jamaicensis (Table 1), serious doubts appear about the species status of this mite. In this context, we report a multidisciplinary approach to the taxonomy, morphology, ecology, and pathology of $K$. jamaicensis.

\section{Materials and methods}

\section{Source of material}

The source of mites was a second year aged female of the Common Chaffinch, Fringilla coelebs, which accidentally died in the mist net during a field study of tick communities of birds in Dumbrava (46.825287 N, 23.220062 E), Romania in March 2011. Careful examination of the specimen revealed the presence of extensive hyperkeratotic lesions on both legs. Few crusts were scraped from one of the legs using a sterile scalpel blade, and mites were collected under a dissection microscope. Individual mites were preserved in $96 \%$ ethyl alcohol for further molecular analysis. The other leg was preserved in $10 \%$ buffered formalin for subsequent histological investigation.

Morphological examination

Intact mite exoskeletons after DNA extraction were mounted on slides using the Faure medium (Evans 1992) and examined under Olympus BX51 light microscope with Nomarski Differential Interference Contrast. Photos were made using a digital camera DP71 and analysed by Helicon Focus 5.1.19 Pro and Helicon Filter 4.93.2 software. All measurements were done on the slides prepared for both the exoskeletons after DNA analysis and traditionally mounted mites (together ten females) using the Cell_D v.2.8.1235 software; the measurements are given in micrometres. The nomenclature of morphological features follows Mironov et al. (2005); body chaetotaxy is applied according to Gaud and Atyeo (1996). English and Latin names of birds are those in Dickinson (2003).

Molecular analysis

Total genomic DNA was extracted from three specimens using a non-destructive method as described by Dabert et al. (2008). A $~ 670$-bp fragment of the mitochondrial cytochrome oxidase subunit I (COI) gene was amplified with bcdF05 and bcdR04 primers (Dabert et al. 2008), and 900 -bp fragments of the nuclear 18S rDNA and 28S rDNA were amplified with $18 \mathrm{Sfw} / \mathrm{rev} 960$ (Dabert et al. 2010) and 28SF0001/28SR0990 (Mironov et al. 2012) primer pairs, respectively. Polymerase chain reactions (PCR) were carried out in $10-\mu$ reaction volumes containing $5 \mu$ Type-it Microsatellite PCR Kit (Qiagen, Hilden, Germany), $0.5 \mu \mathrm{M}$ each primer and $4 \mu \mathrm{l}$ of DNA template using a thermocycling profile of 1 cycle of $5 \mathrm{~min}$ at $95{ }^{\circ} \mathrm{C}$ followed by 35 steps of $30 \mathrm{~s}$ at $95{ }^{\circ} \mathrm{C}, 90 \mathrm{~s}$ at $50{ }^{\circ} \mathrm{C}, 1 \mathrm{~min}$ at $72{ }^{\circ} \mathrm{C}$, with a final step of $5 \mathrm{~min}$ at $72{ }^{\circ} \mathrm{C}$. After amplification, the PCR products were diluted with $10 \mu \mathrm{l}$ of water, and $5 \mu$ l of this was analysed by electrophoresis on a $1 \%$ agarose gel. Samples containing visible bands were directly sequenced in forward direction using $1 \mu \mathrm{l}$ of the PCR product and $40 \mathrm{pmol}$ of the primer. Sequencing was performed with BigDye Terminator v3.1 on an ABI Prism 3130XL analyser (Applied Biosystems).

\section{Histological methods}

After fixation, the whole metatarsal region was embedded in paraffin, sectioned at $5 \mu \mathrm{m}$ and stained with hematoxylineosin (HE) and Goldner's trichrome (GT) methods. Stained sections were examined and photographed using an Olympus BX61 light microscope and a digital camera Olympus DP72 camera.

\section{Results}

Phenotypic determination

The qualitative differences among analysed mites (females) from the Common Chaffinch, $F$. coelebs and the $K$. jamaicensis paratypes described by Fain and Elsen (1967) from the White-Chinned Thrush, Turdus aurantiacus were indiscernible. Our specimens show all the key features of the species: (1) well-developed lateral spine-like structures on propodosoma, epimerites I, widely separated and distinctly L-shaped, (2) sclerotized dorsal ring of the copulatory opening of the bursa copulatrix, (3) presence of trochanteral setae sR III and (4) dorso-terminal positioned anal slit. The shape of the pronotal shield, the sculpture of the hysteronotum (Fig. 1a) and the arrangement of ventral idiosomal setae (Fig. 1c) are also similar to those of the type material illustrated in Fig. 17a, b of Fain and Elsen (1967). On the other hand, these characteristics are slightly different in comparison to the material from Turdus nudigenis. Thus, bases of $3 \mathrm{a}, 3 \mathrm{~b}, \mathrm{~g}$ are arranged in triangle in our material and the type specimens (Fig. 1a, Fig. 17a of Fain and Elsen 1967), but in the material from T. nudigenis setae 3a are 
Table 1 Known host range and distribution of $K$. jamaicensis

\begin{tabular}{|c|c|c|c|}
\hline Family & Species & Locality & References \\
\hline Alaudidae & Alauda arvensis & Denmark & Poulsen 1964 \\
\hline \multirow[t]{2}{*}{ Corvidae } & Corvus brachyrhynchos & USA & Pence 1972 \\
\hline & Corvus frugilegus & England & Keymer and Blackmore 1964 \\
\hline Drepanidae & Hemignathus virens & Hawaii & Gaudioso et al. 2009 \\
\hline \multirow[t]{2}{*}{ Emberizidae } & Loxigilla violacea & Dominican Rep. & Latta and O'Connor 2001 \\
\hline & Pipilo erythrophthalmus & USA & Pence 1970 \\
\hline \multirow[t]{15}{*}{ Fringillidae } & Carduelis cannabina & Denmark & Poulsen 1964 \\
\hline & Carduelis carduelis & Austria & Kutzer 1964 \\
\hline & Carduelis flammea & Denmark & Poulsen 1964 \\
\hline & Carduelis flavirostris & Denmark & Poulsen 1964 \\
\hline & Carduelis spinus & Denmark & Poulsen 1964 \\
\hline & & Austria & Kutzer 1964 \\
\hline & Fringilla coelebs & England & MacDonald 1962; MacDonald and Gush 1983 \\
\hline & & Denmark & Poulsen 1964 \\
\hline & & Czech Rep. & Literák et al. 2005 \\
\hline & Fringilla montifringilla & England & Fain and Elsen 1967 \\
\hline & & Denmark & Poulsen 1964 \\
\hline & Loxia curvirostra & USA & Benkman 2003; Benkman et al. 2001; 2003; 2005 \\
\hline & Pyrrhula pyrrhula & Denmark & Poulsen 1964 \\
\hline & & England & MacDonald and Gush 1983 \\
\hline & Serinus canaria & South Africa & Kaschula 1950 \\
\hline \multirow[t]{6}{*}{ Icteridae } & Agelaius phoeniceus & Canada & Kirmse 1966 \\
\hline & & USA & Olive and Schultz 1952; Herman et al. 1962 \\
\hline & Euphagus cyanocephalus & USA & Fain and Elsen 1967 \\
\hline & Molothrus ater & Canada & Krimse 1966 \\
\hline & Quiscalus quisqula versicolor & USA & Fain and Elsen 1967 \\
\hline & & Canada & Kirmse 1966 \\
\hline \multirow[t]{2}{*}{ Motacillidae } & Anthus sp. & Sri Lanka & Fain and Elsen 1967 \\
\hline & Motacilla capensis & South Africa & Munday 2006 \\
\hline \multirow[t]{2}{*}{ Mimidae } & Dumetella carolinensis & USA & Fain and Elsen 1967 \\
\hline & Mimus polyglottos & Dominican Rep. & Latta and O'Connor 2001 \\
\hline Paridae & Parus atricapillus & Canada & Kirmse 1966 \\
\hline \multirow[t]{4}{*}{ Parulidae } & Dendroica discolor & Dominican Rep. & Latta and O'Connor 2001 \\
\hline & Dendroica palmarum & Dominican Rep. & Latta and O'Connor 2001; Latta 2003 \\
\hline & Dendroica tigrina & Dominican Rep. & Latta and O'Connor 2001 \\
\hline & Microligea palustris & Dominican Rep. & Latta and O'Connor 2001 \\
\hline Sittidae & Sitta carolinensis umbrosa & Mexico & Hardy 1965 \\
\hline Sylviidae & Acrocephalus schoenobaenus & England & Thorne 1971 \\
\hline \multirow[t]{3}{*}{ Turdidae } & Turdus aurantius (type host) & Jamaica & Turk 1950; Fain and Elsen 1967 \\
\hline & Turdus migratorius & USA & Pence et al. 1999 \\
\hline & Turdus nudigenis & Trinidad & Fain and Elsen 1967 \\
\hline \multirow[t]{2}{*}{ Tyrannidae } & Contopus hispaniolensis & Dominican Rep. & Latta and O'Connor 2001 \\
\hline & Myiarchus crinitus & Canada & Kirmse 1966 \\
\hline Incertae sedis (Thraupidae?) & Phaenicophilus palmarum & Dominican Rep. & Latta and O'Connor 2001 \\
\hline
\end{tabular}

set between 3b and g (Fig. 18 of Fain and Elsen 1967). Additionally, we have noticed that the presence of setae $3 \mathrm{~b}$ is variable; in some specimens, these setae were entirely absent (Fig. 1b) or present on one body side only (Fig. 1c). The shape of pronotal shield and the length and location of scapular setae (se, si) show certain degrees of variability in 
Fig. 1 Morphological details of $K$. jamaicensis, female. a Individual sampled on $F$. coelebs, dorsal view, b the same, ventral view, c setae of coxo-genital region in another individual from the same host, d viviparous female with larva, e pronotal shield and scapular setae of $K$. jamaicensis sampled on various host species, 1.F. coelebs (Romania); 2. T. aurantiacus (type host, Jamaica); 3. Carduelis spp. (Austria); 4. Agelaius phoeniceus (USA); 5. T. nudigenis (Trinidad and Tobago); 6. Serinus canaria (South Africa); Source: 2, 4, 5 , 6 (Fain and Elsen 1967); 3 (Kutzer 1964)
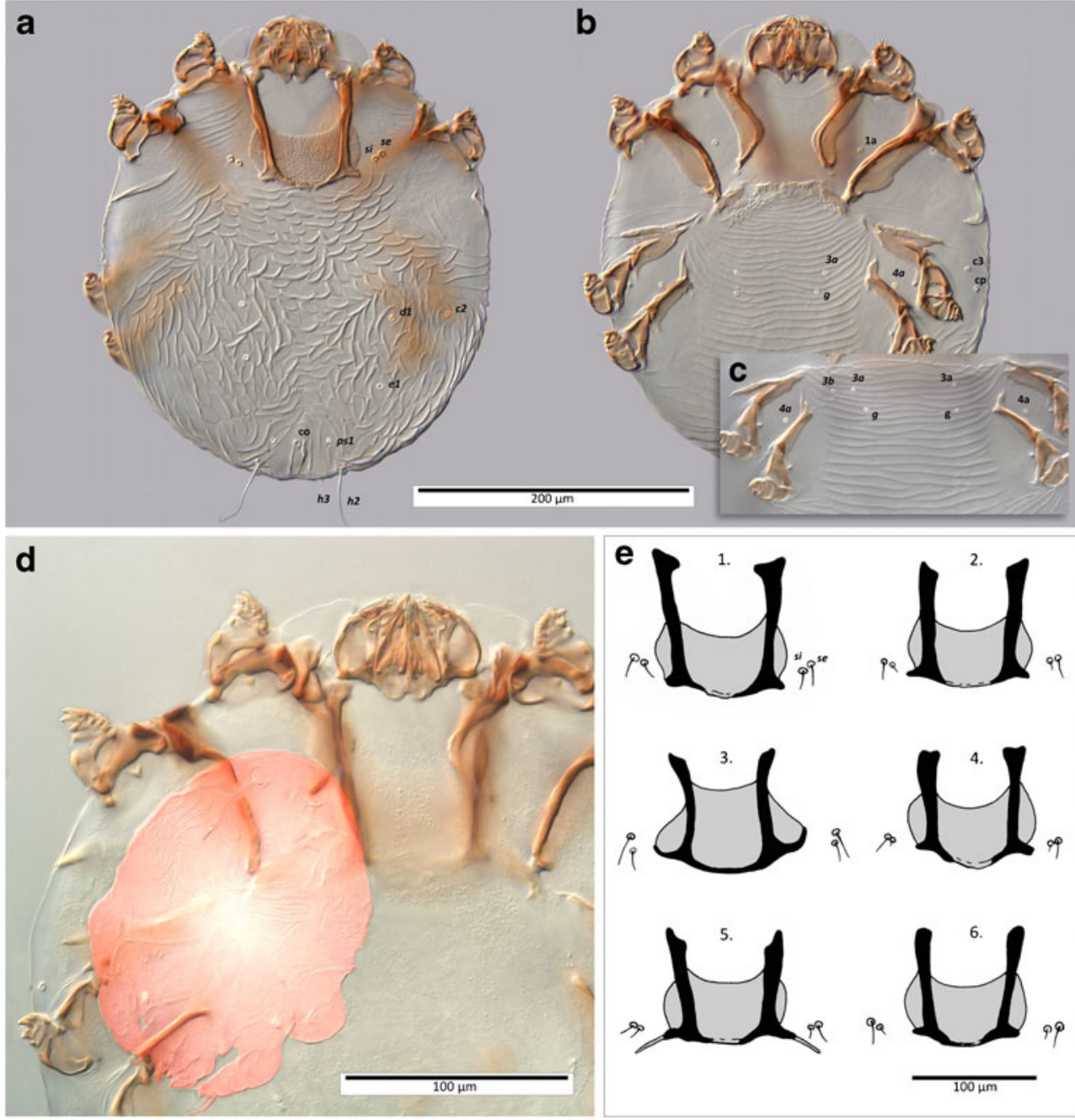

K. jamaicensis found on different hosts and different geographical locations (Fig. 1e).

Comparisons of the biometrical data (i.e. body dimensions, length of setae h2, distances between bases of dorsal setae $\mathrm{d} 1$ and e1) show a great variability of certain measurements between populations infecting various hosts and/or localities or even within a single population (Fig. 2).

\section{DNA barcode}

We sequenced a 631-bp fragment of the mitochondrial COI gene (DNA barcode region chosen by the Consortium for the Barcode of Life, http://barcoding.si.edu) and $651 \mathrm{bp}$ of the nuclear $28 \mathrm{~S}$ rDNA, containing the hypervariable D2 region (Sonnenberg et al. 2007; GenBank accession number JQ037816 and JQ037814, respectively). Since there are no sequence data available in the databases for Knemidocoptes spp. at the COI and D2 loci, we additionally sequenced a fragment of $18 \mathrm{~S}$ rDNA (GenBank accession number JQ037815) to compare it with the corresponding sequence of Knemidocoptes spp. in GenBank database (accession number GQ864317). This 518-base-long sequence differed from the published 18S rDNA in nine positions (509/519 identities, one gap).

Gross and microscopic pathology

Gross lesions (Fig. 3) consisted in severe bilateral hyperkeratosis of the integument starting from the tibiotarsal joint, along the entire length of the tarsometatars and metatarsal joint. On the third phalanx, the hyperkeratotic lesions were milder. Additionally, on the tarsometatars, a whitish smooth film was also observed, suggesting a possible overlapped mycosis. The hyperkeratotic lesions were also evident at the level of joints.

Transversal histological sections of the legs revealed severe lesions involving mostly the skin. The microscopic lesions consisted in hyperkeratosis and hyperplasia of the epidermis enclosing various developmental stages of the mites (Fig. 4). Intraepidermal mites were located in stratum spinosum or stratum corneum. Atrophy of the epidermal layer (Fig. 5) occurred in the areas where mites were 


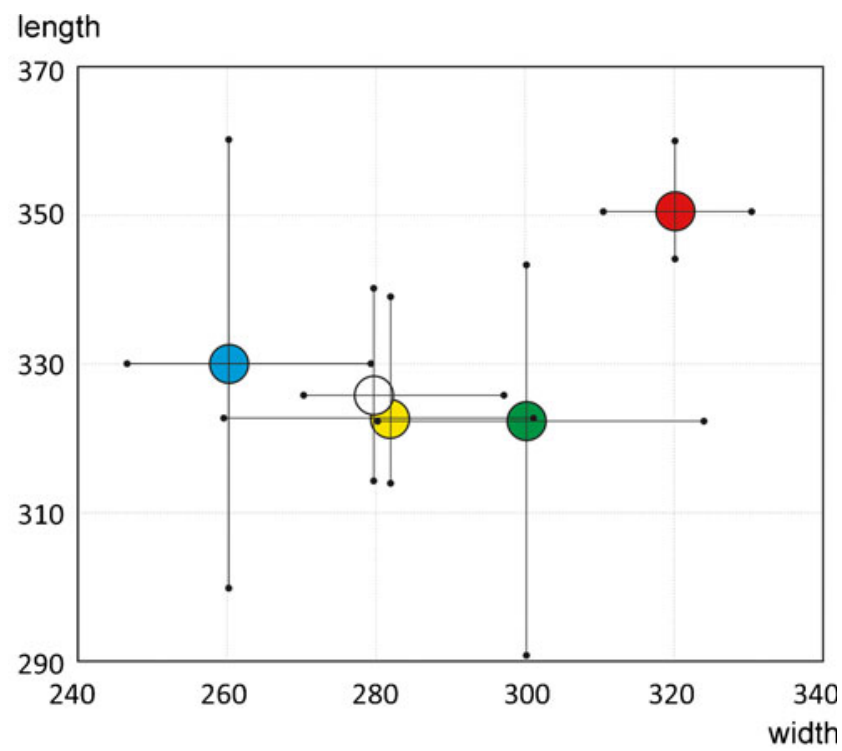

type material from Turdus auranticus (after Fain and Elsen, 1967) additional material from Turdus auranticus (after Fain and Elsen, 1967) material from Fringilla coelebs (own data)

material from Fringilla coelebs (after Fain and Elsen, 1967) material from Turdus nudigenis (after Fain and Elsen, 1967) minimum-maximum

Fig. 2 Dimensions of idiosoma of $K$. jamaicensis sampled on various hosts

present. Deeper layers of the epidermis were not affected. The hyperkeratosis was represented by anucleated squamous epithelial cells in the stratum corneum, indicating an

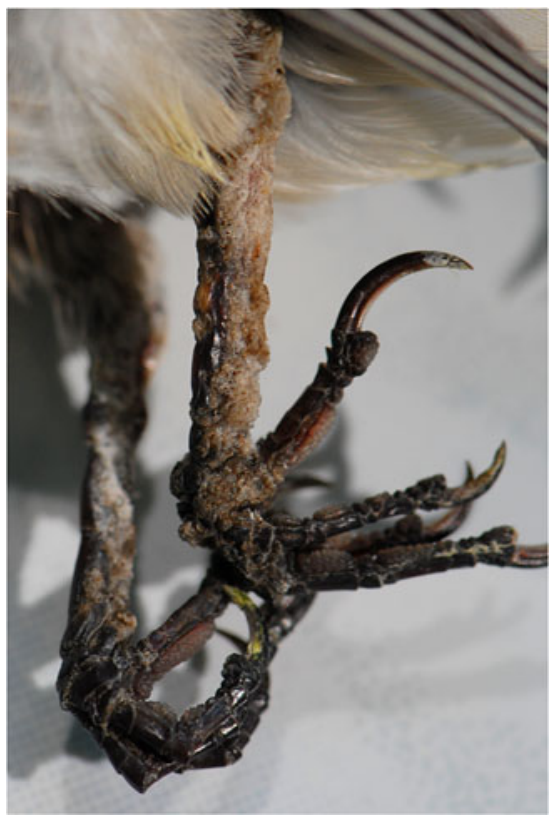

Fig. 3 Gross aspect of the lesions induced by $K$. jamaicensis in $F$. coelebs. Note the severe hyperkeratosis and the whitish film layer on the right leg orthokeratotic hyperkeratosis (Fig. 6), with a compact, less undulating pattern.

The hyperplasia was represented by papillary projections (Fig. 5) of epidermis which protruded the skin surface. Furthermore, a mild intercellular oedema of the epidermis (epidermal spongiosis) was present (Fig. 6). This epidermal spongiosis emphasized the ridges between keratinocytes caused by the widening of the intercellular spaces. However, the keratinocytes remained connected to each other via desmosomal attachment sites. The thickening of the stratum spinosum was associated with acanthosis. Skin inflammation was absent, and no lesions were noticed in the metatarsus bone.

\section{Discussion}

Understanding the complex ecology of parasite-host interaction starts with proper species identification and ends with a fair evaluation of its pathogenicity on the host. In the case of several parasites, species designation is most often based on morphological traits and host specificity and ignores any other ecological factors. In the case of some related parasitic groups, it is surprising how certain species have a limited host spectrum and geographical distribution, while others seem to infect an extremely wide range of hosts over large geographical territories.

Fain and Elsen (1967) in their description of $K$. jamaicensis have firstly reported the wide range of its hosts and noticed a remarkable morphological variation between mite populations inhabiting different passerine bird species. They doubt, however, if the observed differences, mostly of morphometric nature, are sufficient to define some of these populations as separate species. Since then, the host spectrum of $K$. jamaicensis has been greatly expanded. The list of hosts for $K$. jamaicensis counts at least 37 species belonging to 13 passerine families (Table 1), while other Knemidocoptes species and members of remaining knemidocoptin genera have, at most, several host species. Additionally to the enormous number of hosts, $K$. jamaicensis shows a very extensive geographical distribution: Europe, Africa, Asia, North and Central America and Polynesia (Fig. 7). In this context, the question about the taxonomic status of this species is even more up-to-date. It is important to understand if we deal with a polyxenous species of wide trophic specialty or a series of cryptic species adapted to one or a few bird species.

The main problem in assessing the host specificity and in the same time the differences in the pathogenic potential of knemidocoptin mites on various host is the relative lack of reports from clinically healthy wild birds. Most records are consequent to identification of mites in crusty lesions. Evaluation of birds for their asymptomatic carrier status 
Fig. 4 Transversal histological section of the tarsometatars of $F$. coelebs infected with $K$. jamaicensis (GT). Presence of the mites $(a)$, hyperplasia $(b)$ and hyperkeratosis $(c)$

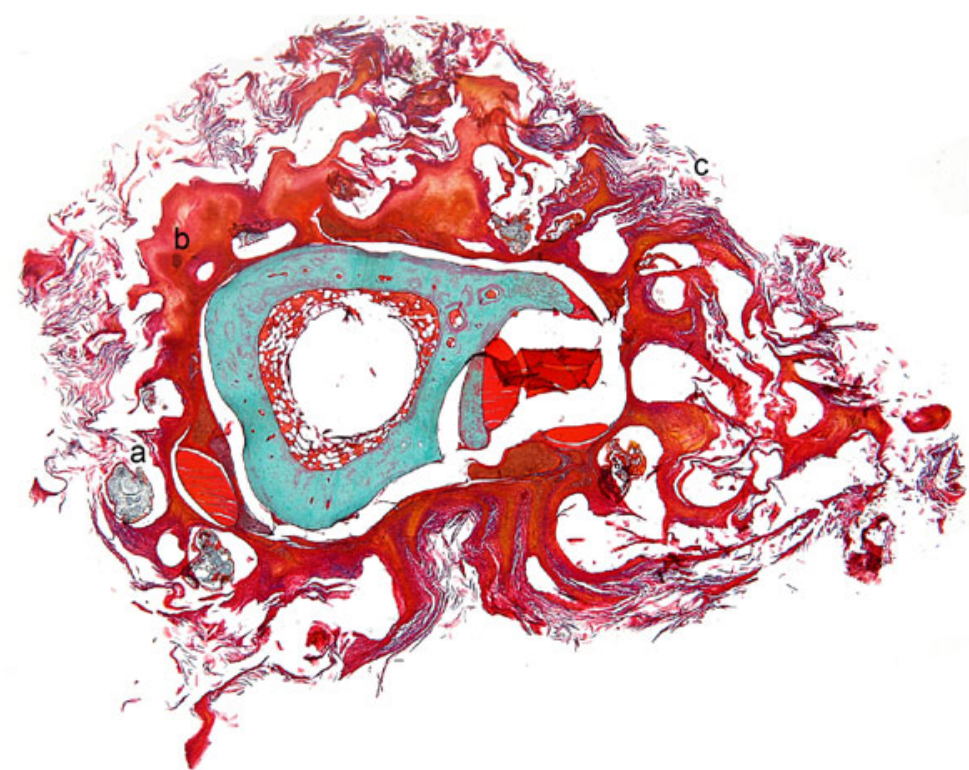

$500 \mu \mathrm{m}$

could be an important step in assessing the real geographic range and host specificity for knemidocoptins in general and $K$. jamaicensis in particular. In this case, a reliable molecular tool (i.e. DNA barcoding) with increased sensibility and specificity is essential. Our paper reports for the first time the DNA barcode sequences of $K$.jamaicensis and, together with the synoptic analysis of host spectrum, geographical distribution and morphological variability it brings important evidences to sustain the hypothesis of multispecies complex for $K$. jamaicensis.

However, from the literature it is not evident if there are any host-dependent differences in the pathogenicity of $K$. jamaicensis. The added value of the histological analysis as a measure of mite's pathogenicity may bring new data on the possible ecological implication of host specificity. Parasites with a high degree of host specificity tend to be less virulent, to avoid co-extinction with their host (SchmidHempel 2011). However, regardless the host specificity, there might be complex influences of the parasite on the host behaviour (arguably, these could be also assimilated to "pathogenic" changes). Most of these behavioural alterations are the result of natural selection of traits which enhance parasite transmission (Moore 2002). Although well known and studied in systems involving trophic transmission, the influence of the ectoparasites on the behaviour of their host has been poorly documented. Ectoparasites
Fig. 5 Transversal section of the tarsometatars of $F$. coelebs infected with $K$. jamaicensis (HE). Atrophy of the epidermal layer $(a)$, papillary projections of the epidermis $(b)$

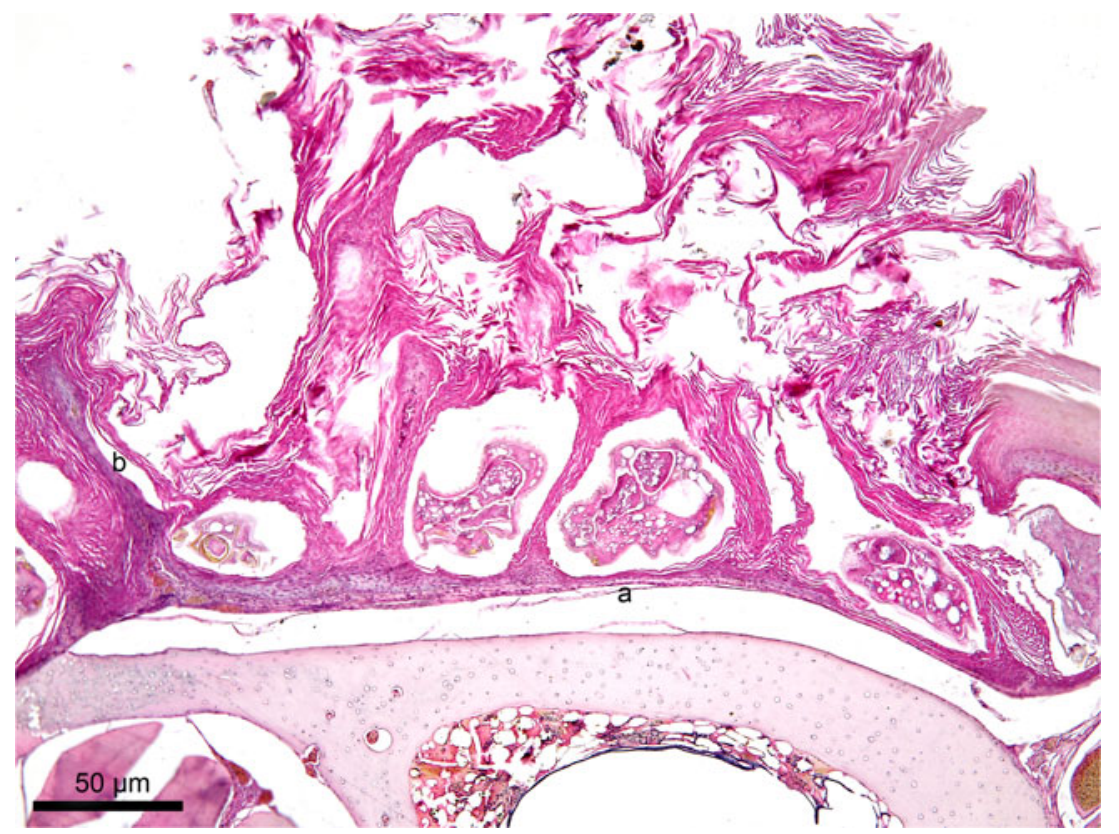


Fig. 6 Transversal section of the tarsometatarsus of $F$. coelebs infected with $K$. jamaicensis (GT). Epidermal spongiosis $(a)$, orthokeratotic hyperkeratosis $(b)$

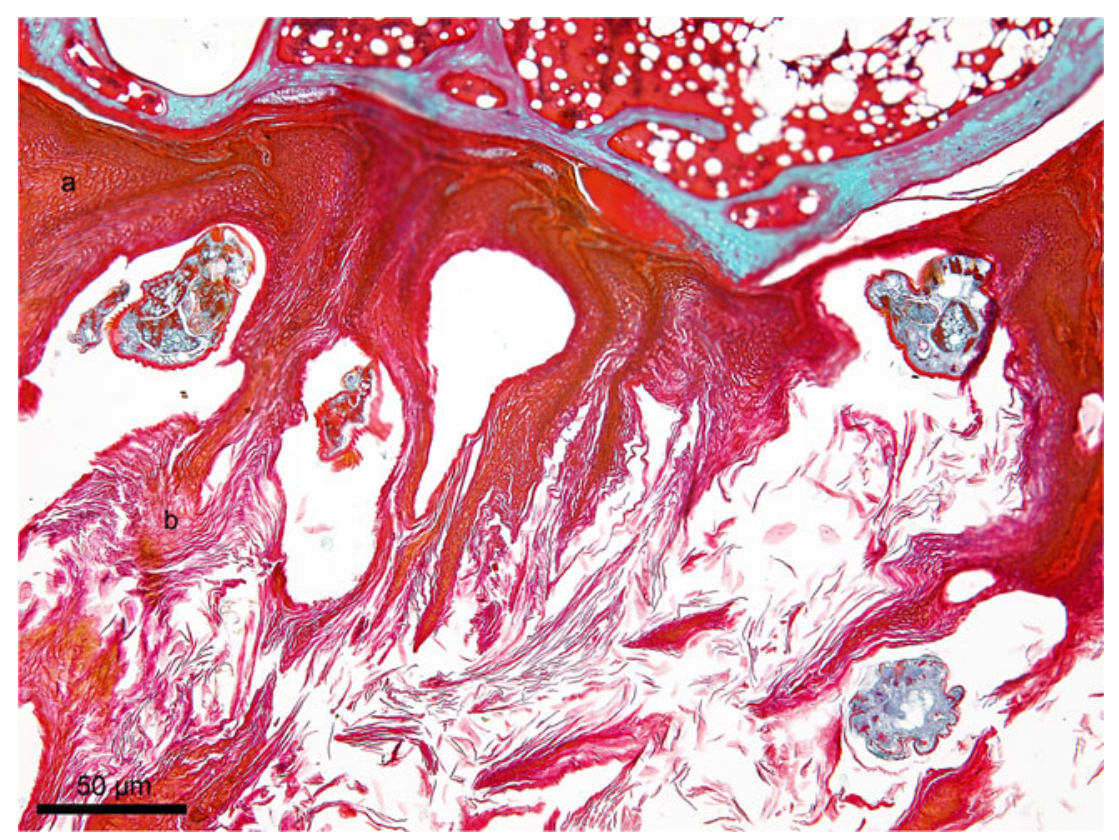

(including knemidocoptin mites) are usually transmitted from host to host by direct contact between infected and non-infected individuals. Alternatively, indirect transmission by actively motile stages is also possible (i.e. roost sites, nest; Pence 2008). There are certain evidences that ectoparasites decrease the mobility of their host to facilitates direct transmission. Guppies (Poecilia reticulata) infected with ectoparasitic monogeneans (Gyrodactylus bullatarudis) are more lethargic and swim oddly attracting other guppies nearby (Scott 1985). Although not proven experimentally, we might hypothesize that birds with severe hyperkeratotic lesions may have a longer and altered resting position (mainly because of reduced mobility of the joints caused by hyperkeratosis), increasing the contact surface between the legs and nest/roost sites.

Our multidisciplinary study (host spectrum and distribution analysis, comparative morphology and chaetotaxy, barcoding and gross/microscopic pathology) represents a new approach for evaluating the taxonomic status of knemidocoptin mites. This encourages similar approaches

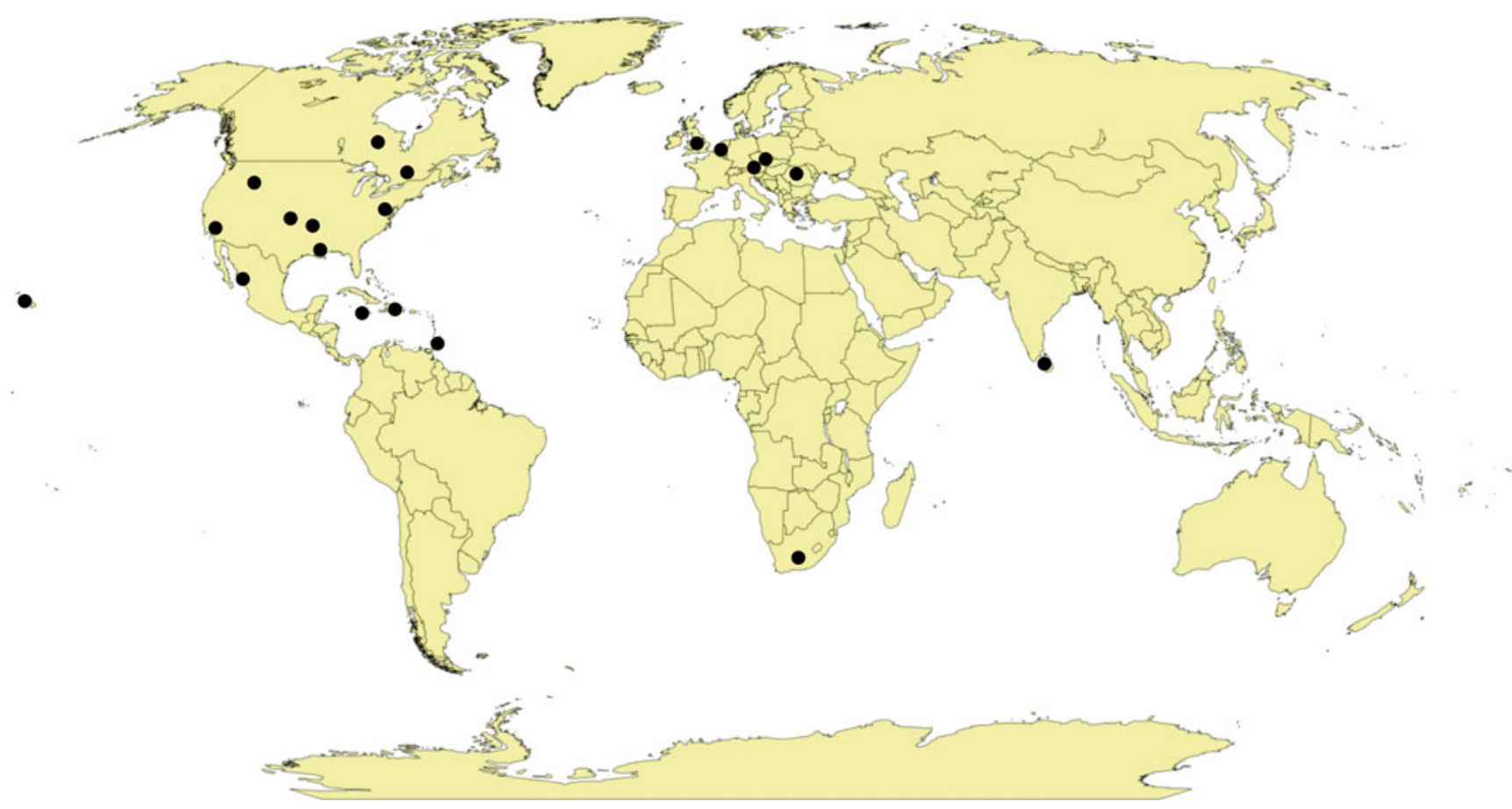

Fig. 7 Geographical distribution of K. jamaicensis 
in future studies worldwide for elucidating the puzzle of "multispecies concept" of $K$. jamaicensis, an important pathogen of birds.

Financial support This work was supported for Mihalca AD and Sándor AD from the grant PCE 236/2011 by UEFISCDI, Romania, and for Dabert $\mathrm{M}$ and Dabert $\mathrm{J}$ from the grant NN303 017937, by Polish MSHE, Poland.

Open Access This article is distributed under the terms of the Creative Commons Attribution License which permits any use, distribution, and reproduction in any medium, provided the original author(s) and the source are credited.

\section{References}

Benkman CW (2003) Divergent selection drives the adaptive radiation of crossbills. Evolution 57:1176-1181

Benkman CW, Holimon WC, Smith JW (2001) The influence of a competitor on the geographic mosaic of coevolution between crossbills and lodgepole pine. Evolution 55:282-294

Benkman CW, Parchman TL, Favis A, Siepielski AM (2003) Reciprocal selection causes a coevolutionary arms race between crossbills and lodgepole pine. Am Nat 162:182-194

Benkman CW, Colquitt JS, Gould WR, Fetz T, Keenan PC, Santisteban L (2005) Can selection by an ectoparasite drive a population of red crossbills from its adaptive peak? Evolution 59:2025-2032

Dabert J, Ehrnsberger R, Dabert M (2008) Glaucalges tytonis sp. n. (Analgoidea: Xolalgidae) from the barn owl Tyto alba (Strigiformes: Tytonidae): compiling morphology with DNA barcode data for taxa descriptions in mites (Acari). Zootaxa 1719:41-52

Dabert M, Witaliński W, Kaźmierski A, Olszanowski Z, Dabert J (2010) Molecular phylogeny of acariform mites (Acari, Arachnida): strong conflict between phylogenetic signal and long-branch attraction artifacts. Mol Phylogent Evol 56:222-241

Dabert J, Mihalca AD, Sándor AD (2011) The first report of Knemidocoptes intermedius Fain et Macfarlane, 1967 (Acari: Astigmata) in naturally infected European birds. Parasitol Res 109:237-240

Dickinson EC (2003) The Howard \& Moore complete check-list of the birds of the world, 3rd edition. Christopher Helm Publishers, London

Evans GO (1992) Principles of acarology. CAB International, Wallingford

Fain A, Elsen P (1967) Les acariens de la famille Knemidocoptidae producteurs de gale chez les oiseaux. Acta Zool Pathol Antverp $45: 1-142$

Gaud J, Atyeo WT (1996) Feather mites of the world (Acarina, Astigmata): the supraspecific taxa. Part 1. Text. Koninklijk Museum voor Midden Afrika Tervuren Belgie Annalen Zoologische Wetenschappen 277:1-193

Gaudioso JM, LaPointe DA, Hart PJ (2009) Knemidocoptic mange in Hawai'i 'Amakihi (Hemignathus virens) on the Island of Hawai'i. J Wildlife Dis 45:497-501

Hardy JW (1965) A spectacular case of cnemnidocoptiasis (scaly-leg) in the white-breasted nuthatch. Condor 67:264-265

Herman CM, Locke LN, Clark GM (1962) Foot abnormalities of wild birds. Bird-Banding 33:191-198

Kaschula VR (1950) "Scaly leg" of the canary (Serinus canaria Linn). J S Afr Vet Assoc 21:117-119

Keymer IF, Blackmore DK (1964) Diseases of the skin and soft parts of wild birds. Brit Birds 57:175-179

Kirmse P (1966) Cnemidocoptic mite infestations in wild birds. Bull Wildlife Dis Assoc 2:86-99
Kutzer E (1964) Die Gattung Knemidocoptes (Acari, Sarcoptoidea). Z Parasitenkd 24:561-577

Langenscheidt M (1958) Embryologische, morphologische und histologische Untersuchungen an Knemidocoptes mutans (Robin et Lanquetin). Z Parasitenkd 18:349-385

Latta SC (2003) Effects of scaley-leg mite infestation on body condition and site fidelity of migratory warblers in the Dominican Republic. Auk 120:730-743

Latta SC, O'Connor BM (2001) Patterns of Knemidokoptes jamaicensis (Acari: Knemidokoptidae) infestations among eight new avian hosts in the Dominican Republic. J Med Entomol 38:437-440

Literák I, Smid B, Dusbabek F, Halouzka R, Novotny L (2005) Coinfection with papillomavirus and Knemidokoptes jamaicensis (Acari: Knemidokoptidae) in a chaffinch (Fringilla coelebs) and a case of beak papillomatosis in another chaffinch. Veterinarni Medicina 50:276-280

MacDonald JW (1962) Chaffinch with cnemidocoptic mange. Brit Birds 55:421

MacDonald JW, Gush GH (1983) Finches with knemidocoptic mange. Ringing and Migration 4:191-192

Mironov SV, Bochkov AV, Fain A (2005) Phylogeny and evolution of parasitism in feather mites of the families Epidermoptidae and Dermationidae (Acari: Analgoidea). Zool Anz 243:155-179

Mironov SV, Dabert J, Dabert M (2012) A new feather mite species of the genus Proctophyllodes Robin, 1877 (Astigmata: Proctophyllodidae) from the Long-tailed Tit Aegithalos caudatus (Passeriformes: Aegithalidae) - morphological description with DNA barcode data. Zootaxa 3253:54-61

Moore J (2002) Parasites and the behavior of animals. Oxford University Press, New York

Munday TL (2006) The search for the reason(s) causing feet abnormalities in the cape wagtail (Motacilla capensis). Dissertation, University of Johannesburg

Olive JR, Schultz V (1952) Scaly-leg (Cnemidocoptiasis) in the redwinged blackbird (Agelaius phoeniceus). Auk 69:90-91

Pence DB (1970) Knemidokoptes jamaicensis Turk from the rufoussided towhee in Louisiana. J Med Entomol 7:686

Pence DB (1972) Picicnemidocoptes dryocopae gen. et sp. n. (Acarina: Knemidokoptidae) from the pileated wood-pecker, Dryocopus pileatus L., with a new host record for Knemidokoptes jamaicensis Turk. J Parasitol 58:339-342

Pence DB (2008) Acariasis. In: Atkinson CT, Thomas NJ, Hunter DB (eds) Parasitic diseases of wild birds. Wiley-Blackwell, Iowa, pp 527-536

Pence DB, Cole RA, Brugger KE, Fischer JR (1999) Epizootic podoknemidokoptiasis in American robins. J Wildlife Dis $35: 1-7$

Poulsen H (1964) Scaly-leg in captive birds. The Avicultural Magazine $70: 69$

Schmid-Hempel P (2011) Evolutionary parasitology: the integrated study of infections, immunology, ecology, and genetics. Oxford University Press, New York

Scott ME (1985) Experimental epidemiology of Gyrodactylus bullatarudis (Monogenea) on guppies (Poecilia reticulata): short- and long-term studies. In: Rollinson D, Anderson RM (eds) Ecology and genetics of host-parasite interactions. Academic Press, London, pp 21-38

Sonnenberg R, Nolte AW, Tautz D (2007) An evaluation of LSU rDNA D1-D2 sequences for their use in species identification. Front Zool 4:6

Thorne CJR (1971) Grotty leg. Wicken Fen Report 3:17-18

Turk FA (1950) A new species of parasitic mite, Cnemidocoptes jamaicensis, a causative agent of scaly-leg in Turdus aurantiacus. Parasitology 40:60-62 